UDC 004.942

DOI https://doi.org/10.32838/2663-5941/2019.6-2/40

Yanenko M.V.

National Technical University of Ukraine "Igor Sikorsky Kyiv Polytechnic Institute"

Karpluk Ye.S

National Technical University of Ukraine "Igor Sikorsky Kyiv Polytechnic Institute"

\title{
NOVEL APPROACH OF MODULAR EIT ARCHITECTURE BASED ON BALANCED CONTROLLED CURRENT SOURCE ARRAY
}

The article introduces a new approach to the architecture of impedance tomography devices based on Howland current sources with grounded load for using in code division impedance tomography devices. For maintaining the current balance in the circuit, a feedback loop was created, based on operational amplifiers. Computer modeling of electrical circuits in the ORCAD PSPICE environment was used to study the proposed approach. Modeling of circuits used models of real components. The Cole model was used as a phantom to simulate both the active component of the impedance, which described the conductivity of intracellular and extracellular substances, and the reactive, which described the conductivity of cell membranes. Two approaches have been modeled, the first of which is classic and transformer based, the second is a proposed approach based on controlled current sources. Transfer characteristic of single current sources with different active load were obtained. The classical approach has been considered in terms of the overall characteristics of the device. The impedance of the simulated phantom of the patient is also estimated using ideal current sources and real current sources. The two approaches have been compared in the paper using different methods of estimating the accuracy of measuring the phantom impedance in a given frequency band. The rms value and the maximum deviation from the real value were chosen to estimate accuracy. Also, for comparison of circuit approaches, the operating frequency band for impedance measurement was determined. The proposed principle can be used to create impedance tomography devices using code division channels. Also, the proposed approach has a lower cost, is more compact and less expensive. This approach is modular, which allowed to increase the number of tomograph channels.

Key words: Electrical Impedance Tomography, Howland current source, code channels dividing, modeling, patient phantom model.

Introduction. Electrical Impedance Tomography (EIT) is method of medical imaging using multichannel impedance measurements through electrodes attached to body. Image of body part or organ in such system is obtained by solving a mathematical problem. Estimated image represents impedance of tissue. Invented in 1989 [1, p. 40], EIT has made significant progress and is still developing.

EIT is a non-invasive, inexpensive, radiation-free and portable medical imaging technique [2, p. 89]. Also, such instrument can be applied for real time continuous patient monitoring, including Intensive Care Unit (ICU) patients monitoring, and for diagnostics.

Because of such advantages, Impedance Tomography has been successfully used in many areas of medicine. EIT was used for breast cancer detection [3], which can be used as primary screening for early detection of cancer [4]. Also, EIT is used for non-invasive hemodynamic monitoring [5], which is especially important for patients with heart disease. EIT has a wide range of applications of in lung monitoring, as example for lung ventilation and perfusion [6], lung recruitment monitoring [7], pneumothorax detection [8] not only for adult, but also for infants, especially after cardiac surgery [9]. EIT was applied in neonatology for brain injuries detecting [10], and brain activity imaging [11].

Electrical impedance measurements techniques. Classic way of electrical impedance measurements is applying single-frequency sinusoidal current signal between pair of electrodes and measuring resulting voltage [12]. The new generation of EIT systems allows us to generate a wide range of alternative currents. Using sinusoidal signal of more than one frequency is called multi-frequency EIT [13] [14], which is helpful to reveal more information from image otherness on different frequencies for study conductivities of various tissues [15]. Such systems require multiplexor for high speed multiplexing between channels. Block-scheme is shown on Fig. 1. 


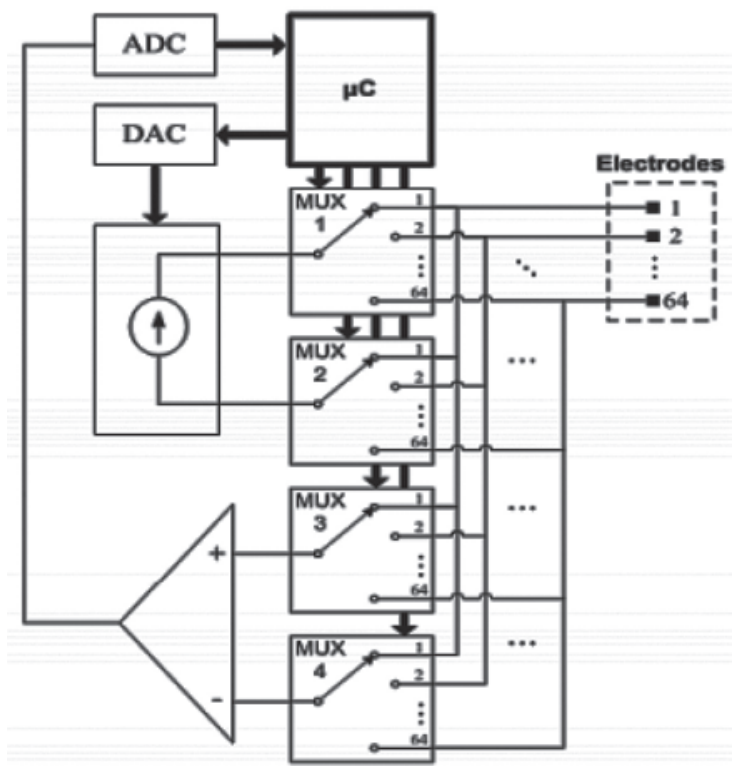

Fig. 1. High-level architecture of multiplexor-based EIT [13]

In past decade much research has focused on the way of dividing channels without multiplexor, which reduce power consumption and cost. The first way is Frequency Division Multiplexing (FDM). In FDMbased systems each current signal has unique frequency [16]. Measured signal could be divided on independent signals by Fast Fourier Transform (FFT) [17].

Another way is using unique orthogonal symbol sequence for each channel - Code Division Multiplexing (CDM) [18]. The principle is modulating signal of each channel using binary digital code. The codes which may be used are called Gold Codes, also used in the Global Positioning System (GPS) to encode the signals from the GPS satellite constellation. Codes of this type are generally referred to as pseudorandom noise (PRN) sequences, as they appear to be random and have the characteristics of noise. The spectral characteristics of the CDM input signal effectively interrogate the sample over a wide range of frequencies, and the output signals can be transformed to produce a spectrum, giving us simultaneous wideband spectroscopy on all channels.

Channel dividing is achieved by using cross-correlation principle.

CDM principle requires appropriate solutions for current injection circuit in the area of circuit design: device should be low-cost, low-energy consumption, wide-frequency range, high output impedance. Previous researchers proposed circle with transformer [19] for current injecting and patient isolating, but this approach requires more free space on the board.
Howland current sources with grounded load for CDM EIT may be used for EIT. The schematic diagrams of enhanced Howland circuit are shown in Fig. 2.

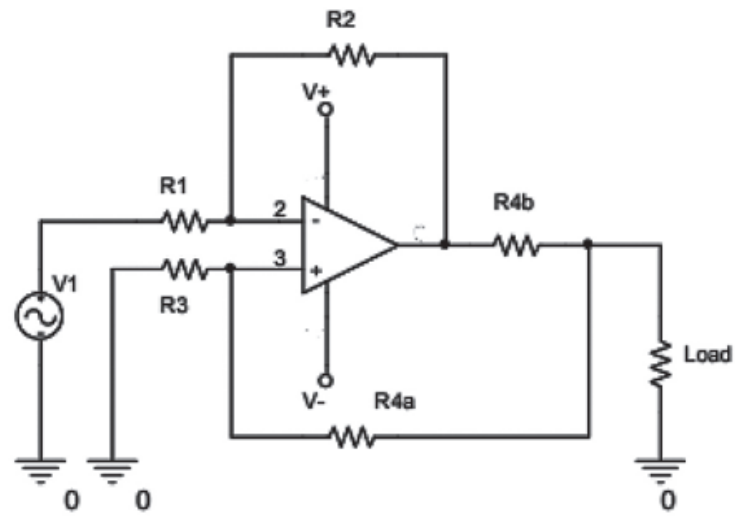

Fig. 2. Enhanced Howland circuit [20]

The structure of enhanced Howland circuit uses only one operational amplifier and some passive components. Such scheme was used for multifrequency EIT [20][21]. The output current of this circuit is computed by equation (1):

$$
I_{L}=-\frac{V_{1} R_{2}}{R_{4 b} R_{1}} .
$$

The output current $I_{L}$ is controlled by signal $V_{1}$ and resistors, but independent of load. Ideal output impedance is presented by equation (2):

$$
R_{\text {out }}=\frac{R_{1} R_{4 b}\left(R_{3}+R_{4 a}\right)}{R_{2} R_{3}-R_{1}\left(R_{4 a}+R_{4 b}\right)} .
$$

When resistors ratio achieve balance according to equation: $R_{2} R_{3}=R_{1}\left(R_{4 a}+R_{4 a}\right)$, ideal output impedance is equal to infinity.

Because of such wide range of applications, such systems have special requirement to hardware. EIT devices should be portal, low-cost, low-energy consumption and patient-safe. The purpose of our study is proposing solutions to this problem for nowel hardware architecture of EIT, and also comparing different approaches between them for describing advantages and disadvantages each of them.

\section{New EIT approach evaluation}

Based on the shortcomings of existing devices, new EIT techich with code division multiplexing was proposed. New principle implements the measurement of patient impedance using a grounded load Howland current sources. For current balancing current feedback circuit were used for proposed scheme.

Proposed module-based approach with Enhanced Howland current source is represented on fig. 3 . 


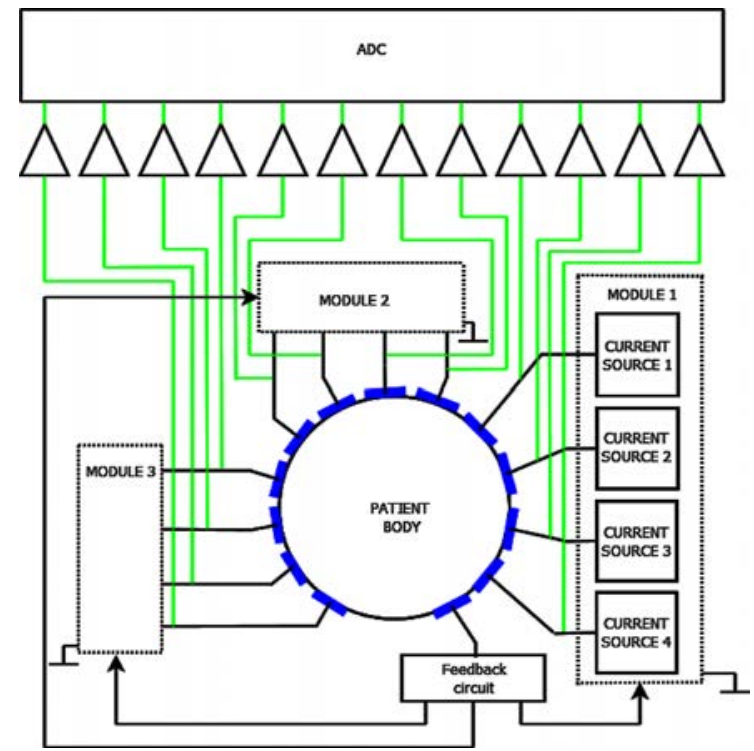

Fig. 3. New EIT technique block diagram

Each CURRENT SOURCE block on Fig. 3 is Enhanced Howland circuit. All modules are connected general ground. Each MODULE block consists four Howland current sources, for all of them current offset from current feedback is added for unbalanced current compensating. Such modules can be combined in any number for increasing channels number.

Feedback circuit is presented on figure 4.

Amplifier $U_{5}$ and resistor $R_{29}$ form feedback amplifier, in which depth of current feedback depends of resistance. Second part consists of amplifier $U_{6}$ and resistors $R_{30}, R_{31}$, which is inverting amplifier.

Also, proposed approach for EIT was compared with transformer scheme [18][19] to determine optimal solution. One voltage-to-current converter based on transformer is depicted on fig.5., where $R_{1}, R_{2}$ is winging resistance, $R_{\text {measure }}$ is precision resistor for indirect impedance measurements.

a) Scheme modeling and evaluation;

Simulation of all three approaches were provided in Orcad Pspice. As result of AC analysis, impedance response were evaluated for technique comparison with ideal current sources and real current sources between two approaches. As a measure of the difference from the real impedance, the standard deviation (3) and maximum deviation (4) were chosen.

$$
\begin{gathered}
\delta_{2}=\frac{\sqrt{\frac{1}{N} \sum_{i=1}^{N}\left(X_{i}-Y_{i}\right)^{2}}}{\sqrt{\frac{1}{N} \sum_{i=1}^{N} X_{i}}} \\
\delta_{\max }=\max \left|\frac{X-Y}{X}\right|
\end{gathered}
$$

Both equation (3) and (4) use the same values, where $X$-measured phantom impedance with ideal current sources, $Y$ - measured phantom impedance with real current sources.

\section{b) Patient model;}

As a patient model Single Cole Model [22] was chosen. Commonly, equivalent circuit (fig. 6) with parameters of the Cole bioimpedance model is widely used to represent the electrical impedance of biological tissues. The circuit parameters that represent the impedance of a biological tissue and describe both the magnitude and phase of the impedance.

The model parameters $R_{0}, R_{1}$ are associated with tissue fluids and $C, \alpha$ are associated with the cellular membranes of the tissues [23]. Parameters values were chosen as $R_{0}=2 \mathrm{kOhm}, R_{1}=20 \mathrm{kOhm}, C=35 \mathrm{hF}$.

For patient phantom modeling Cole circuits were connected between all electrodes with principle "onewith-each-one".

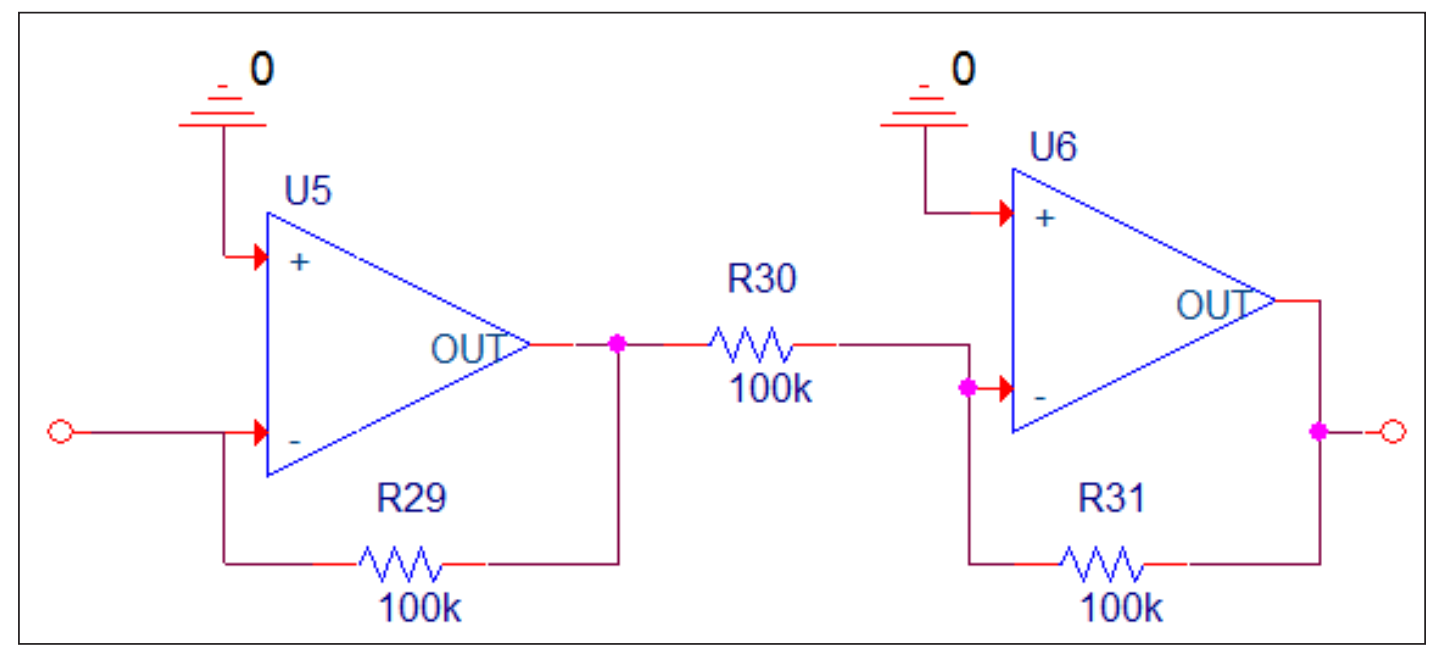

Fig. 4. Current feedback circuit 


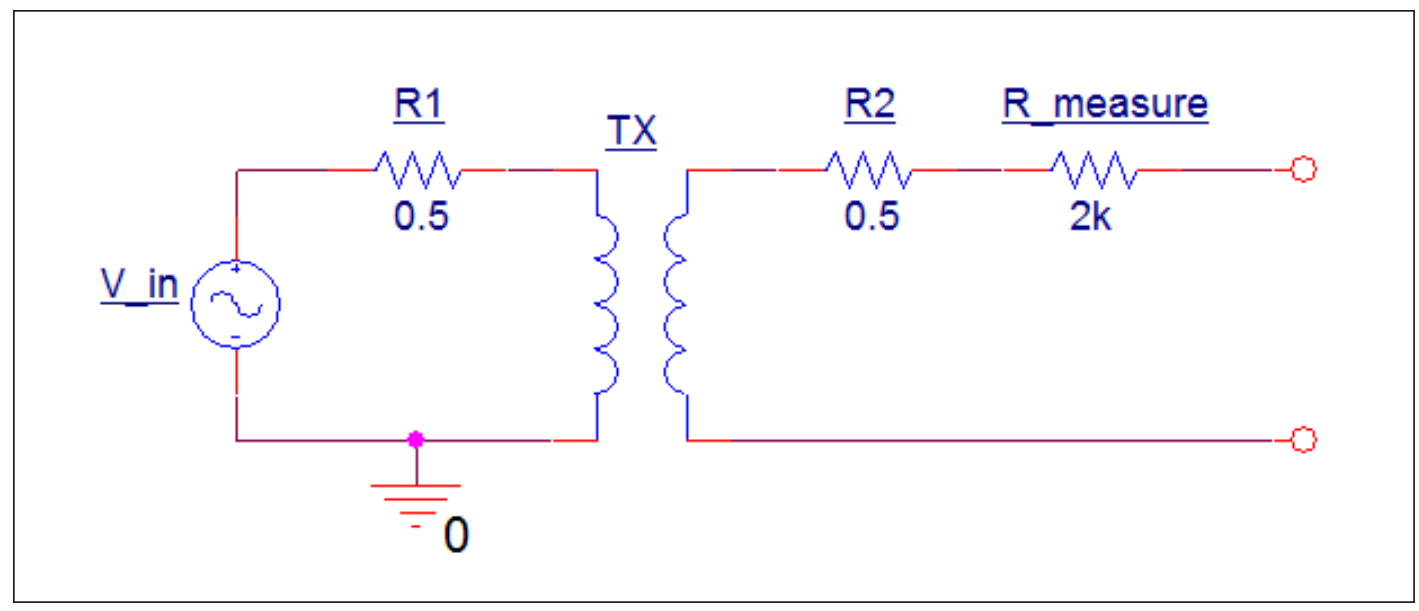

Fig. 5. Transformer-based circuit

c) Materials;

The ADA4891-1, is CMOS, high speed amplifiers that offer high performance at a low cost. The amplifier feature is true single-supply capability, with an input voltage range that extends $300 \mathrm{mV}$ below the negative rail. In spite of low cost, the ADA4891-1 provides high performance and versatility.

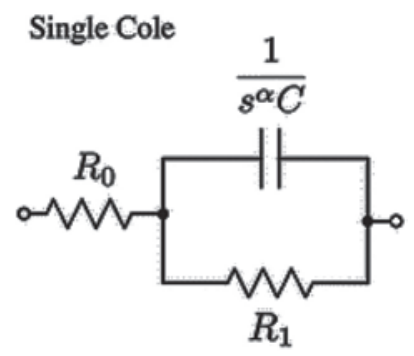

Fig. 6. Single Cole equivalent circuit [23]

\section{Results}

a) Classic transformer-based solution amplitude-frequency characteristic

Single transformer based circuit with active load were simulated. Also, the current source transfer char- acteristic was acquired depending on the load resistance (fig. 8). The load resistance was varied from $1 \mathrm{kOhm}$ (' $\square$ ') to $50 \mathrm{kOhm}$ ('*') with step $5 \mathrm{kOhm}$.

According to figure 8 output current increases with load resistance. Also, output current increases on the frequency interval to $1 \mathrm{kHz}$ due to winding inductance, and after that is stable.

Four transformer sources were simulated with patient phantom. Impedance frequency response were obtained from simulated data using formula (3) for impedance divider according to figure 5 . In equation $3 U_{\text {load }}$ is amplitude frequency response, $Z_{\text {load }}$ is load impedance, $U_{2}$ is secondary winding voltage.

$$
U_{\text {load }}=U_{2} \frac{Z_{\text {load }}}{R_{\text {measure }}+Z_{\text {load }}}
$$

Impedance frequency response of patient phantom was imposed on fig. 9 for comparing.

According to figure 9, two curves are superimposed, both of them have a decrease on frequency response in the interval from $100 \mathrm{~Hz}$ to $1 \mathrm{kHz}$ due to nature of patient model.

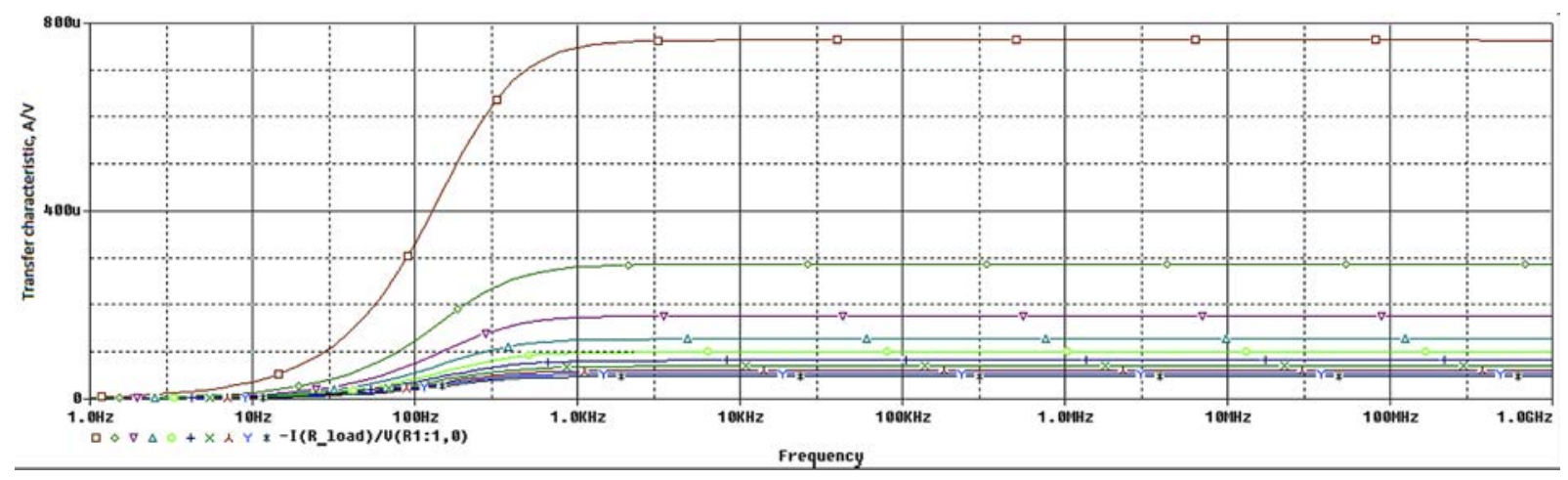

Fig. 8. Controlled current source transfer characteristic of transformer scheme 


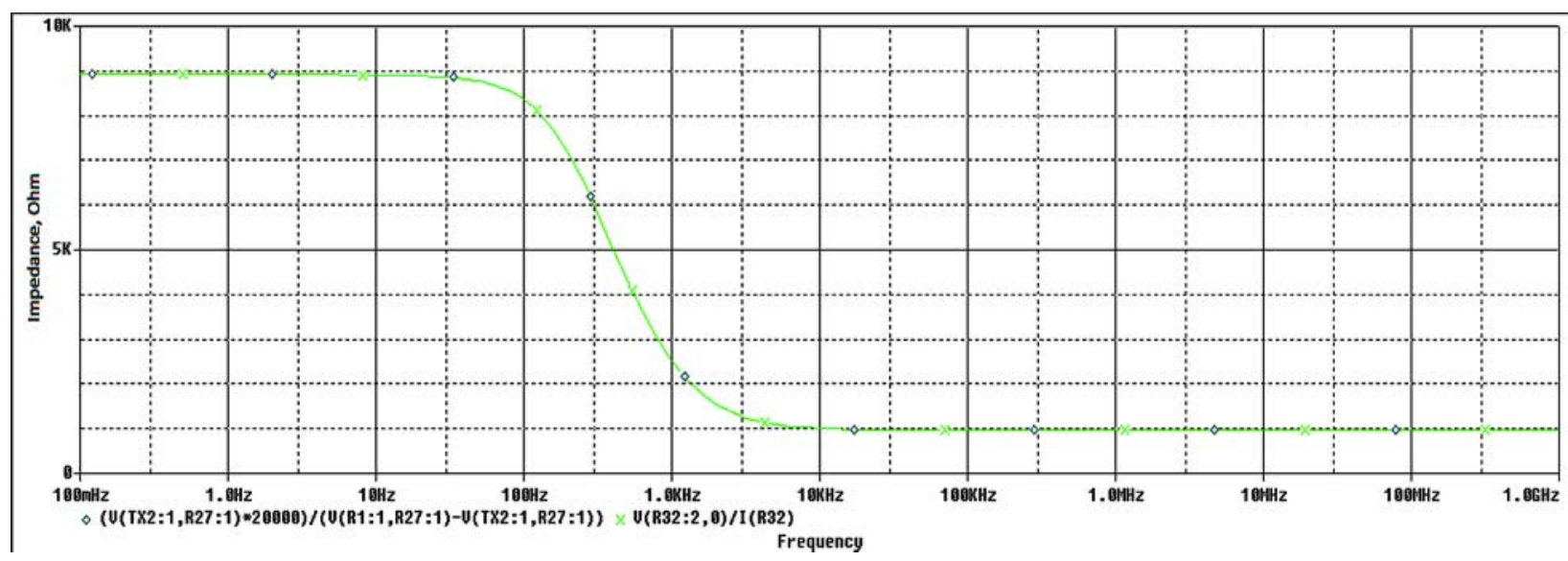

Fig. 9. Impedance response of patient phantom with ideal current sources ( $x$ ) and transformer based current circuit (o)



Fig. 10. Controlled current source transfer characteristic of Howland current source



Fig. 11. Impedance of Howland current sources

with feedback ( line with ' $\square$ ') and patient phantom impedance with ideal current sources ( line with ' 0 ')

b) New approach modeling result

Single Howland current source with grounded active load were simulated for obtaining transfer characteristic (fig. 10). Characteristic was acquired depending on the load resistance, which was varied from $1 \mathrm{kOhm}($ ' $\square$ ') to $100 \mathrm{kOhm}$ ('*') with step $10 \mathrm{kOhm}$.

Impedance frequency response were obtained from simulated data of Howland current sources with feedback circuit and patient phantom. Impedance fre- 
quency response of patient phantom was imposed on fig. 11 for comparing.

According to figure 11, two curves are superimposed on frequency interval from $1 \mathrm{kHz}$ to $5 \mathrm{MHz}$. Impedance increasing after $10 \mathrm{kHz}$ is affected by amplitude response of non-ideal amplifiers. Sharp decline and then peak impedance values is caused by frequency dependence of feedback circuit due to real amplifiers models.

Approaches were obtained with chosen norm (3) and (4) in frequency band from $1 \mathrm{kHz}$ to $5 \mathrm{MHz}$. The results are presented in the table 1.

\begin{tabular}{|c|c|c|}
\hline & Transformer-based approach & Proposed approach \\
\hline$\delta_{2}$ & $8.11 \mathrm{E}-6$ & 0.0017 \\
\hline$\delta_{\max }$ & $1.43 \mathrm{E}-5$ & 0.0064 \\
\hline
\end{tabular}

Conclusion. Proposed approach can be used for EIT applications. Despite a narrower band and slightly low accuracy than moduled transformer based design, such approach has advantages. Impedance measurement error of proposed scheme is not higher than $0.64 \%$. The upper frequency of the band $(5 \mathrm{MHz})$ is equal to some researchers proposed in other publications [18, p. 200].

\section{References:}

1. Eyuboglu, B.M., Brown, B.H., Barber, D.C. In vivo imaging of cardiac related impedance changes. IEEE Eng. Med. Biol. Mag. 1989. Vol 8. P. 39-45.

2. Talha Ali Khan, Sai Ho Ling Review on Electrical Impedance Tomography: Artificial Intelligence Methods and its Applications. Algorithms. 2019. Vol. 12, № 5, P. 88.

3. V. Cherepenin, A. Karpov, A. Korjenevsky, V. Kornienko, A. Mazaletskaya, D. Mazourov, D. Meister A 3D electrical impedance tomography (EIT) system for breast cancer detection. Physiol. Meas. 2001. Vol. 22. 2001. P. 9-18.

4. Akhtari-Zavare M., Latiff L.A. Electrical Impedance Tomography as a Primary Screening Technique for Breast Cancer Detection. Asian Pac J Cancer Prev. 2015. Vol.16, № 14. P. 55-57.

5. Leonhardt S., Pikkemaat R., Stenqvist O., Lundin S. Electrical Impedance Tomography for hemodynamic monitoring. Conf Proc IEEE Eng Med Biol Soc 2012. 2012. P. 122.

6. Leonhardt S., Lachmann B. Electrical impedance tomography: the holy grail of ventilation and perfusion monitoring? Intensive Care Med. 2012. Vol. 38 № 12. P. 1917-29.

7. Long Yun, Huai-wu He, Knut Moller, Ine'z Frerichs, Dawei Liu, Zhanqi Zhao Assessment of Lung Recruitment by Electrical Impedance Tomography and Oxygenation in ARDS Patients. Medicine. 2016. Vol. 95, № 22 .

8. Miedema M., Frerichs I., de Jongh F.H., van Veenendaal M.B., van Kaam A.H. Pneumothorax in a preterm infant monitored by electrical impedance tomography: a case report. Neonatology. 2011. Vol. 99, № 1. P. 10-3.

9. Krause U., Becker K., Hahn G., Dittmar J., Ruschewski W., Paul T. Monitoring of regional lung ventilation using electrical impedance tomography after cardiac surgery in infants and children. Pediatr Cardiol. 2014. Vol. 35, № 6. P. 990-7.

10. McDermott B., O'Halloran M., Porter E., Santorelli A. Brain haemorrhage detection using a SVM classifier with electrical impedance tomography measurement frames. PLoS ONE. 2018. Vol. 13, №7.

11. David S. Holder Electrical impedance tomography (EIT) of brain function. Brain Topography. 1992. Vol. 5, №2. P. 87-93.

12. L. C. Moro, R. W. Porto Single Frequency Electrical Impedance Tomography System with Offline Reconstruction Algorithm. 2015 IEEE 6th Latin American Symposium on Circuits \& Systems (LASCAS), 2015.

13. Christos Dimas, Petros Tsampas, Nikolaos Ouzounoglou, Paul P. Sotiriadis Development of a Modular 64-Electrodes Electrical Impedance Tomography System", 2017 6th International Conference on Modern Circuits and Systems Technologies (MOCAST), 2017.

14. Susana Aguiar Santos, Thomas Schlebusch, Steffen Leonhardt Simulation of a Current Source with a ColeCole Load for multi-frequency Electrical Impedance Tomography. 35th Annual International Conference of the IEEE EMBS Osaka. 2013.

15. Shi Xuetao, Dong Xiuzhen, You Fusheng, Fu Feng, Liu Ruigang High precision Multifrequency Electrical Impedance Tomography System and Preliminary imaging results on saline tank. Proceedings of the 2005 IEEE Engineering in Medicine and Biology 27th Annual Conference Shanghai. 2005. P. 1493-95.

16. Yair Granot, Antoni Ivorra, Boris Rubinsky Frequency-Division Multiplexing for Electrical Impedance Tomography in Biomedical Applications. Hindawi Publishing Corporation International Journal of Biomedical Imaging. 2007. P. 1-9.

17. Boxiao Liu, Guoxing Wang, Yongfu Li, Lei Zeng, Hui Li, Yue Gao, Yixin Ma, Yong Lian, Chun-Huat Heng A 13-Channel 1.53-mW 11.28-mm2 Electrical Impedance Tomography SoC Based on Frequency Division Multiplexing for Lung Physiological Imaging. 2019 IEEE International Solid- State Circuits Conference (ISSCC). 2019. P. 1-11. 
18. L. McEwan A., S. Holder D., Tapson J. and van Schaik A. WIDE-BANDWIDTH, HIGH FRAME RATE ELECTRICAL IMPEDANCE TOMOGRAPHY / SPECTROSCOPY - A Code Division Multiplexing (CDM) Approach. In Proceedings of the First International Conference on Biomedical Electronics and Devices. 2008. P. 196-203.

19. A. McEwan, J. Tapson, A. van Schaik, D.S. Holder Electrode Circuits for Frequency and Code Division Multiplexed Impedance Tomography. 2007 IEEE Biomedical Circuits and Systems Conference. 2007. P. 130-133.

20. Cheng-Yu Chen, Yi-Yu Lu, Wen-Lung Huang, Kuo-Shang Cheng The Simulation of Current Generator Design for Multi-Frequency Electrical Impedance Tomograph. Proceedings of the 28th IEEE EMBS Annual International Conference New York City. 2006.

21. Yinan Wang, Nan Li, Hongqi Yu, Zhaolin Sun, Hongshan Nie, Hui Xu Study on Wide-band Voltage Controlled Current Source for Electrical Impedance Tomography. 2011 Second International Conference on Intelligent System Design and Engineering Application. 2011. P. 1499-1502.

22. Todd J. Freeborn, Ahmed S. Elwakil, Brent Maundy Variability of Cole-model bioimpedance parameters using magnitude-only measurements of apples from a two-electrode configuration. International Journal of Food Properties. 2017. Vol. 20, P. 507-519.

23. Todd J. Freeborn, Bo Fu, Fatigue-Induced Cole Electrical Impedance Model Changes of Biceps Tissue Bioimpedance. Fractal Fract. 2018. Vol. 2. P. 27.

\section{Яненко М.В., Карплюк Є.С. НОВИЙ ПІДХІД ДО МОДУЛЬНОЇ АРХІТЕКТУРИ ІМПЕДАНСНОЇ ТОМОГРАФІЇ, ЗАСНОВАНИЙ НА КОНТРОЛЬОВАНОМУ ДЖЕРЕЛІ СТРУМУ}

У статті наведено новий підхід до модульної архітектури пристрою імпедансної томографії на основі керованих джерел струму Хоуланда із заземленим навантаженням для застосування в приладах імпедансної томографії із кодовим розділенням каналів. Для підтримання балансу струму в схемі було використано коло зворотного зв'язку, щуо створено на основі операційних підсилювачів. Для дослідження запропонованого підходу було використано комп 'ютерне моделювання електричних схем у середовищі ORCAD PSPICE. Під час моделювання схем було використано моделі реальних компонентів. Як фантом було використано модель, засновану на моделі Коула, щзо імітує як активний складник імпеданса, який своєю чергою імітує як провідність клітинної та позаклітинної речовини, так і реактивну, щэо імітує провідність клітинних мембран. Було промодельовано два підходи, перший із них є класичним i заснований на використанні трансформаторів, другий - запропонований підхід на основі керованих джерел струму. Класичний підхід було розглянуто з точки зору габаритних характеристик приладу. Також досліджується імпеданс змодельованого фантому пацієнта із використанням ідеальних джерел струму і реальних джерел струму. Два підходи було порівняно в статті за допомогою різних методів оиінки точності вимірювання імпедансу фантому в визначеній смузі частот. Було отримано функиії передачі окремих джерел струму за різного активного навантаження. Для оцінки точності було обрано середньоквадратичне значення та максимальне відхилення від реального значення. Також для порівняння схемних підходів було визначено смугу робочих частот для вимірювання імпедансу. Запропонований принщип може бути використаний для створення пристроїв імпедансної томографії із використанням кодового розділення каналів. Також запропонований підхід має нижчу вартість, є більш компактним та мало споживаючим. Такий підхід є модульним, щзо дозволяє збільщувати кількість каналів томографа.

Ключові слова: імпедансна томографія, джерело струму Хоуланда, Кодове розділення каналів, моделювання, модель фантому пацієнта. 